\title{
An Investigation into Cultural Events and Tourism on the Isle of Man
}

\author{
Brychan Thomas ${ }^{1}$, Lisa Powell ${ }^{1} \&$ Simon Thomas ${ }^{1}$ \\ ${ }^{1}$ South Wales Business School, University of South Wales, Pontypridd, United Kingdom \\ Correspondence: Brychan Thomas, South Wales Business School, University of South Wales, Pontypridd, CF37 \\ 1DL, United Kingdom. Tel: 44-078-4770-9640. E-mail: brychan.thomas@southwales.ac.uk
}

Received: August 15, $2020 \quad$ Accepted: September 28, $2020 \quad$ Online Published: October 30, 2020

\begin{abstract}
This paper investigates the significance of cultural events for the development of tourism on the Isle of Man. Historically the Isle of Man captured tourists from areas around the Irish Sea including England, Wales, Scotland, and Northern Ireland. This was especially the case with working-class tourists from the industrial North of England, North Wales, Dublin and Belfast. These tourism markets were prominent in the late $19^{\text {th }}$, and early and mid $20^{\text {th }}$ centuries. Recent tourist data shows a fall in visitor numbers to the Isle of Man which has taken effect in post war years. In order to explore this decline, and the significance of cultural events for the development of tourism in recent years, a number of research methods have been deployed involving secondary data to assess tourism development and tourism sector growth determinants. As a consequence an investigation was undertaken involving sequential parts. Part one considered trends in the $19^{\text {th }}, 20^{\text {th }}$ and early $21^{\text {st }}$ centuries drawing primarily on secondary data, existing research and archival material. Part two investigated cultural events to provide findings and analysis for the tourism industry on the Island. Lastly, part three assessed the nature and importance of events according to the modern evolution of the sector. External (international) and internal (island) influences on development were considered. From the findings conclusions showing prominent issues from the trends observed have enabled consideration of the importance of cultural events for tourism development.
\end{abstract}

Keywords: Isle of Man, cultural events, tourism

\section{Introduction}

The purpose of the paper is to investigate an important topical issue in the island setting of the Isle of Man. There is considerable development of research being undertaken in the area of events, and the relationship to community development (Powell et al., 2010, 2011) is quite significant in some cases. Cultural events can be of relevance not only to a wider readership in tourism and events but also island and land researchers due to having a specific influence on an island setting (Thomas and Thomas, 2012; Thomas et al., 2017). This study explores the significance of cultural events for the evolution of tourism on the Isle of Man. Recent tourist data has shown a fall in visitor numbers to the Island which has taken effect in the post war years (Canavan, 2015). Research methods have included secondary data and an evolutionary analysis to assess this tourism development. The research question addressed "what are the processes involved in the apparent decline of the tourism industry in relation to the growth of cultural events on the Isle of Man". The study presents an analysis of the impact of cultural tourism, based on the methodology used in previous research by the authors (Thomas and Thomas, 2012; Thomas et al., 2017), which has been evolved for the research to enable future comparative analysis and field research. Since the research is based on analysis of the latest secondary data available it will be representative to the managers, scholars, and readers in this situation. A contribution of the study to current knowledge is that it highlights the importance of cultural events for the development of tourism on the Isle of Man.

\section{Background}

In terms of an overview the Isle of Man is located in the middle of the Irish Sea with Ireland to the west, Scotland north, Northern England east and North Wales south. In the 33 miles from the cliffs of the Calf of Man to the Point of Ayre, and 11 miles wide from Douglas in the east to Peel in the west, unless a narrow inland glen, there is scarcely a place from which the ocean in its changing states is not seen (Figure 1). In its length, there is a chain of hills from North Barrule (1,842ft.) to Snaefell $(2,024 \mathrm{ft}$.), and from Snaefell to Cronk-ny-Jay-Laa [sic Cronk-nyIree-Lhaa] (1,145ft.), "the hill of the rising day". From these the sun can be seen rising from the sea and setting in the west. The lure (Johnson, 2016) of the Island is that sea views are perhaps some of the most striking in the United Kingdom, except for the north-west coast of Scotland. But in the Island they are broader and almost as bold; the rugged masses of Spanish Head, the mellow colouring of the Calf, and the wide expanse of waters on 
every side, dotted by herring boats for the Manx "kipper" industry, is a scene which is unequalled in any of the British coasts. With few trees this creates land views harsh and cold, with general coast views, coves and glens open to the sea, which characterise Manx scenery. With cool summers and mild winters there is vegetation abnormal to this latitude. There are cottages with high hedges, hanging flowers and shrubs (Spectator, nd).

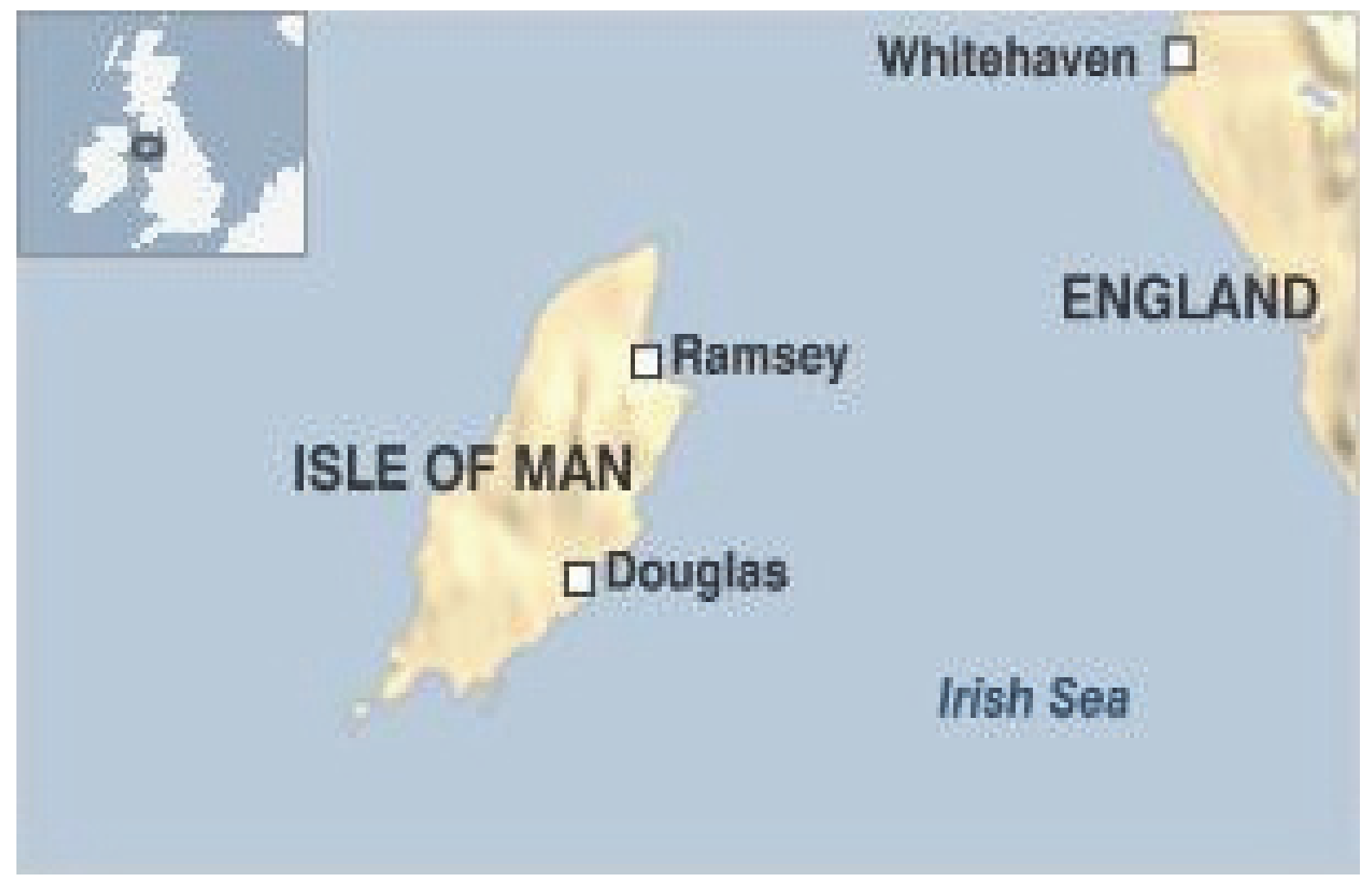

Figure 1. Map of the Isle of Man (Source: BBC News, 21 April 2016)

The current population of the Isle of Man is 85,154 , based on the latest United Nations estimates, and ranks 202 in the list of countries (and dependencies) by population with a population density of 149 per $\mathrm{KM}^{2}$ (386 people per mile $)$ and with a land area of $570 \mathrm{KM}^{2}(220$ sq. miles) some $53.4 \%$ of the population is urban $(45,437$ people in 2020) (Worldometers, 2020). The Worldometers' RTS algorithm (Worldometers, 2020), which processes data collected from the United Nations Population Division delivers the Isle of Man Population Live counter which shows a continuously updated estimate of the current population of the Isle of Man. The population of the Isle of Man is shown in Figure 2 and plots the total population count for the 1 July each year for the years 1955 to 2020 . This shows the overall total population for both sexes and all ages as estimated by the United Nations, Department of Economic and Social Affairs, Population Division (United Nations, 2020). 


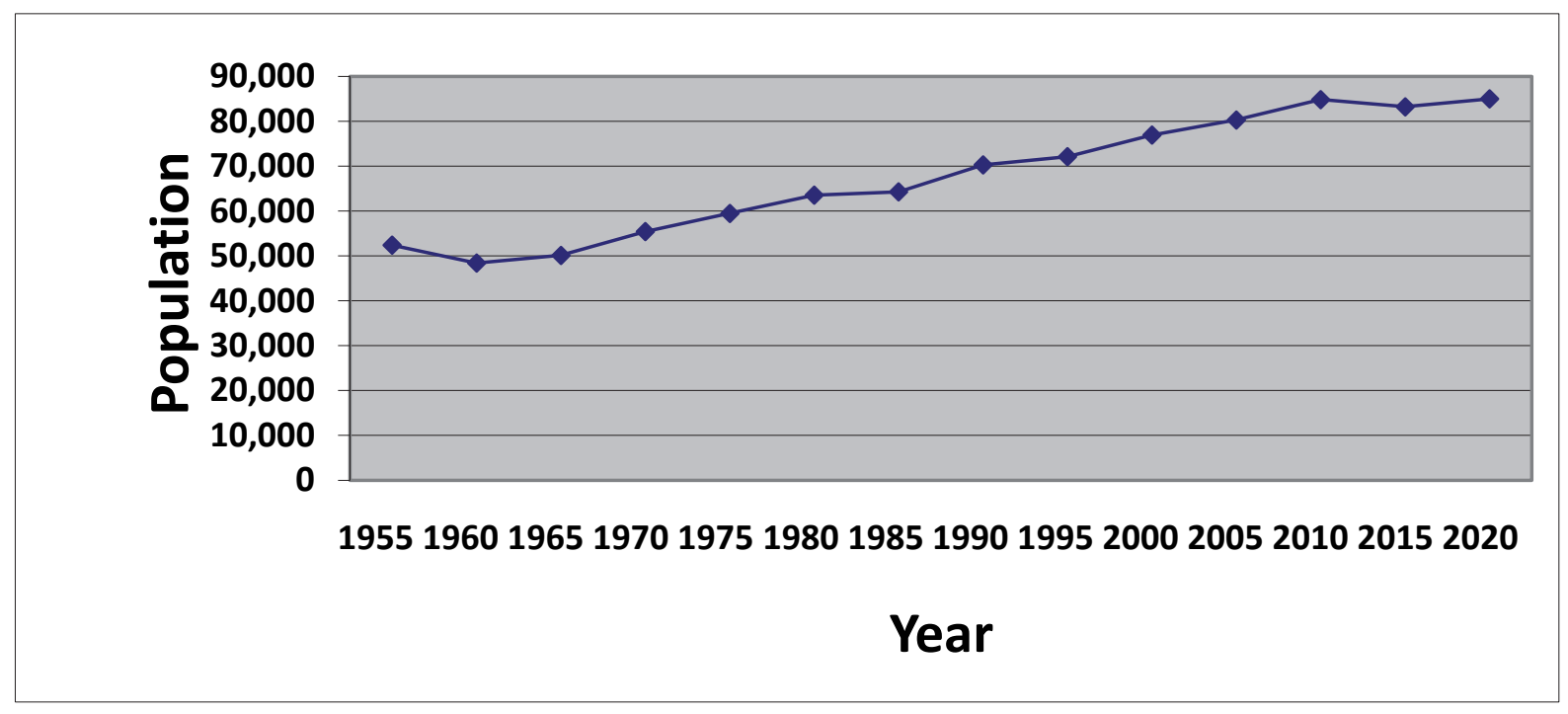

Figure 2. Population of the Isle of Man (Worldometers www.Worldometers.info)

The forecast of the Isle of Man population is shown in Figure 3 for the years 2020 to 2050 (Worldometers, 2020).

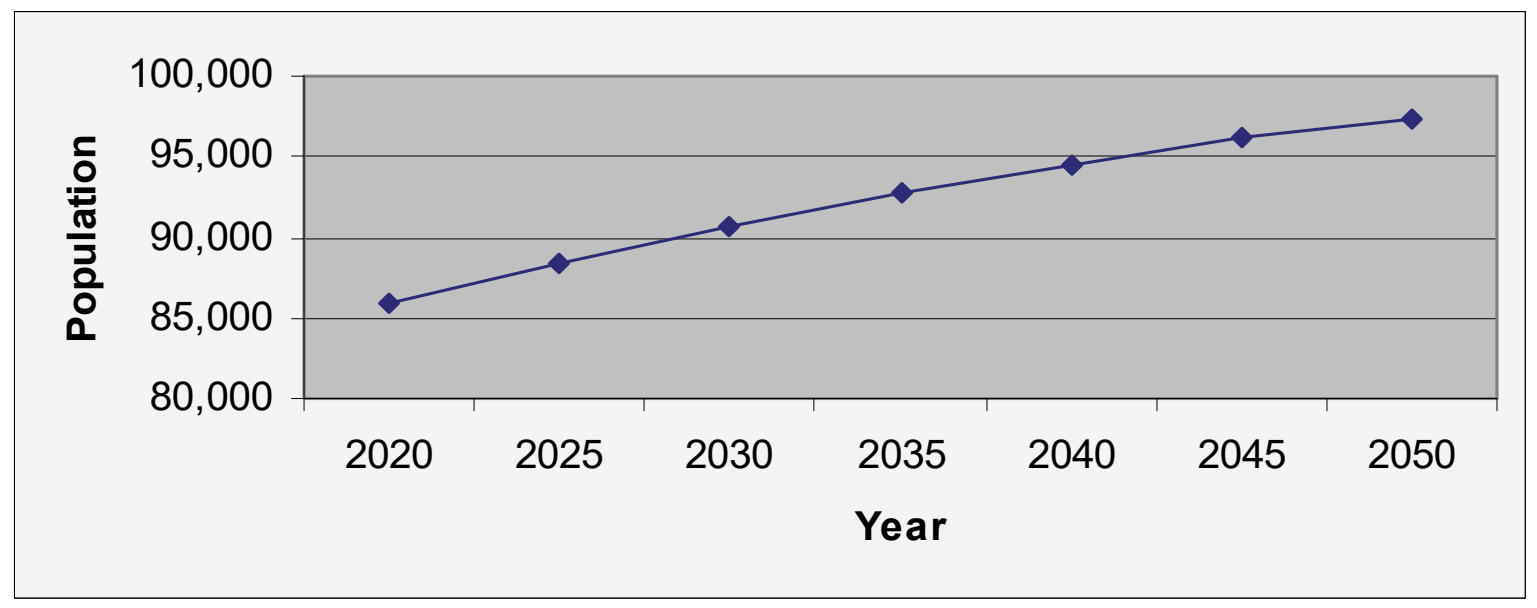

Figure 3. Isle of Man Population Forecast (Worldometers www.Worldometers.info)

The issue of possible implications on developing tourism destinations both physically, socially, culturally and economically, is something that needs to be considered. Tourists can easily disregard the dangers they can provoke without thinking about the impact of their visitation. The aim of this research paper is to discuss the significance of cultural events for the development of tourism on the Isle of Man.

\section{Cultural Events and Cultural Tourism}

Cultural tourism has been defined as 'not merely associated with visiting monuments and sites, which is the traditional view of cultural tourism, it also includes consuming the way of life in different destinations' (Mousavi et al. 2016, p. 74). It is in this light that this study considers the impact of culture on tourism (OECD, 2009) in terms of cultural events in an island setting. Further to this considerable growth has been witnessed by the events sector in the last thirty years being an important aspect of tourism, heritage and culture economies today (Bowdin et al, 2006; Yeoman et al, 2004). Events range from local/community events to large/mega events for classification purposes (Langen and Garcia, 2009) and these include the Football World Cup and Olympic Games. Cultural events contribute to the socioeconomic basis of communities according to how nations, communities and individuals are defined. Cultural events will reflect more than one concept, and the interpretation of culture. In Yeoman et al's (2004) view culture is seen as a process and represents activities including high cultural events, 
such as Ballet and Opera, and popular contemporary events stimulated by television, sport and music.

In the field of tourism an important contributor to the cultural economy is considered to be cultural events. As an important influence the cultural economy has been transformational for the engines of economic growth (Malecki, 1991 ) in the later 1980s, 1990s, and more recently. Economies that shift have supported growth in the cultural arts sector due to the sector not only being a source of knowledge and learning, but also an important contributor to indirect and direct benefits for economies. Growth in cultural events was unprecedented during 2000-05. In 2002 the Edinburgh Fringe Festival, for instance, outsold and created greater revenue than the Commonwealth Games in Manchester the same year. According to Yeoman et al (2004), cultural events stimulate investment, create jobs and enrich people's lives. United Kingdom cities have adopted the cultural agenda, using the brand potential of cultural events to provide profile, image and distinction to the regions of cities.

It has been indicated by the British Arts Festivals Association (BAFA) (2008) only 8\% of attendees at cultural events will travel 50 miles or more. However, this does not account for cultural events that are high profile which attract wider interest and a higher number of tourists who stay. It can therefore be deduced that staying tourists could have a significant impact on Isle of Man's cultural and related events.

\section{Research Methodology}

\subsection{Research Focus}

In order to investigate the significance of cultural events in terms of the tourism industry on the Isle of Man an evolutionary research methodology was followed (Seldes, 1985), which was undertaken in three distinct parts taking into consideration previous understanding for future insight (Sheeley, 2002). The three parts involved a systematic process (Umphrey, 2002) (Table 1) employing various methods for each part (Schumaker and McMillan, 1993). The study created a meta-narrative in order to understand the full logic of the methodology, instead of studying why people at different times had differing views about Isle of Man tourism. Adopting appropriate methods was considered the most suitable approach due to these being used previously in similar situations even though some hidden underlying trends might not be related.

\subsection{Research Question}

The research study question has explored "what are the processes involved in the apparent decline of the tourism industry in relation to the growth of cultural events in the Isle of Man?" In order to consider this question primary sources (census data) and secondary sources (work of historians) were investigated (Young, 1987; Montgomery, 1999; Leedy, 2001) in the first part of the research to obtain an understanding of the trends in the modern evolution of the tourism industry in the Isle of Man. Data analysis and synthesis of findings (Sheeley, 2002) were undertaken in the second part to identify the various factors. Part three of the research involved consideration of the importance of cultural events to determine the conclusion. This provided an overview of developments and trends (Engels, 1980).

\subsection{Research Strategy}

The research study strategy is shown in Table 1.

Table 1. Research Strategy

\begin{tabular}{|c|c|c|}
\hline \multicolumn{3}{|c|}{ Research Focus and Methods of the study } \\
\hline Part (P) & Research Focus & Research Methods \\
\hline $\mathrm{P} 1$ & $\begin{array}{l}\text { Trends in the modern evolution of the } \\
\text { tourism industry. }\end{array}$ & $\begin{array}{l}\text { Secondary data, existing research and archival } \\
\text { material. }\end{array}$ \\
\hline $\mathrm{P} 2$ & $\begin{array}{l}\text { Investigation of cultural events to } \\
\text { provide findings and analysis. }\end{array}$ & $\begin{array}{l}\text { Popular cultural events investigated according to } \\
\text { their development and nature. }\end{array}$ \\
\hline P3 & $\begin{array}{l}\text { Importance of cultural events and } \\
\text { response to the research question }\end{array}$ & $\begin{array}{l}\text { Internal strengths/weaknesses and external } \\
\text { opportunities/threats. }\end{array}$ \\
\hline
\end{tabular}

The parts of the research outlined in Table 1 have investigated the following aspects of the significance of cultural events for the evolution of the tourism industry.

P1 - Trends in the modern evolution of the tourism industry 
In the first part of the research, following providing an introduction and background to the study in terms of the demographics of the Isle of Man, cultural events and cultural tourism, trends in the modern evolution of the tourism industry were investigated. This involved secondary data, existing research and archival material.

\section{P2 - Investigation of cultural events to provide findings and analysis}

Following consideration of the tourism industry on the Isle of Man and visitor data, as well as history and cultural heritage, this part of the research investigated popular cultural events on the Isle of Man to provide findings and analysis.

\section{P3 - Importance of cultural events and response to the research question}

The third and last part of the research considered the importance of cultural events and the response to the research question. These aspects of the research are considered in the conclusion involving internal strengths/weaknesses and external opportunities/threats for cultural events and tourism on the Isle of Man. Further to this a tourism strategy is proposed outlining the need to invest in eco, pilgrimage, heritage and transport tourism.

More generally, the analytical process followed in this research explored issues in the evolution of the industry including both island (internal) and international (external) influences which are highlighted in the conclusion. From this a summary of the salient issues arising from the trends has been undertaken, providing direct analysis of the importance of cultural events.

\subsection{Research Results}

Results of the study are provided in the following sections of the article within the section headings of the tourism industry on the Isle of Man, history and cultural heritage, cultural events: findings and analysis. This is followed by the conclusion involving a tourism strategy proposal.

\section{Tourism industry on the Isle of Man}

The Isle of Man has been referred to as a 'romantic escape' tourism destination. In comparison to other areas of the British Isles, accessibility in terms of infrastructure is more developed. There are air links to major airports in Ireland, the Channel Islands, UK and abroad, which means that flying to the Island is easy. Daily flights are operated by most airlines with those from the UK about thirty minute's duration. The Island's airport, Ronaldsway, is located to the south of the Isle of Man which is regularly serviced by a bus route to take passengers to the destination where they are staying. Additionally, there are taxis and car hire from the airport to travel to destinations.

Travel to the Island by sea is by foot or car. A regular ferry service to the Isle of Man is operated by the Steam Packet Company from Belfast, Birkenhead, Dublin, Heysham and Liverpool using two vessels - the conventional Ben-my-Chree and the ninety six metre wave piercing catamaran, Manannan. Cruise ships make visits, and these arrive in Manx waters every year from around the globe. A cruise visit to the Irish Sea is not complete without visiting the Island.

In the main harbour of the Island's capital of Douglas vessels can be moored or, for bigger ships, Douglas Bay. There are short distances between activities and attractions on the Isle of Man, and visitors can enjoy the Island's sights and heritage when ashore. Whatever the form of travel people take they will be able to enjoy this "gem" located in the Irish Sea (Visit Isle of Man, 2019).

The Isle of Man Passenger Survey 2018 (Isle of Man Government, 2019) showed that the number of visitors to the Island increased by some 0.8 percent from the previous year to 308,263 . For the number of non-business visitors who stayed in paid accommodation in 2018 the total figure increased by 15,878 visitors to 145,738 , a 12\% increase (Isle of Man Government, 2019). The average length of stay by visitors on the Island (including business visitors) was estimated at 5.5 nights (Isle of Man Government, 2019). During 2018 the estimated total expenditure by visitors to the Island was 132.8 million pounds, an increase of $7.3 \%$ on 2017 with an average visitor spend per visit of 489 pounds increasing by 12.2\% (Isle of Man Government, 2019). In 2018 a comparable proportion of visitors came from the North West of England to 2017 which was 29.1\%, with a sizeable proportion of visitors from outside the United Kingdom and Ireland as well as the South East (Isle of Man Government, 2019). Figure 4 shows the number of visitors by mode of travel. 


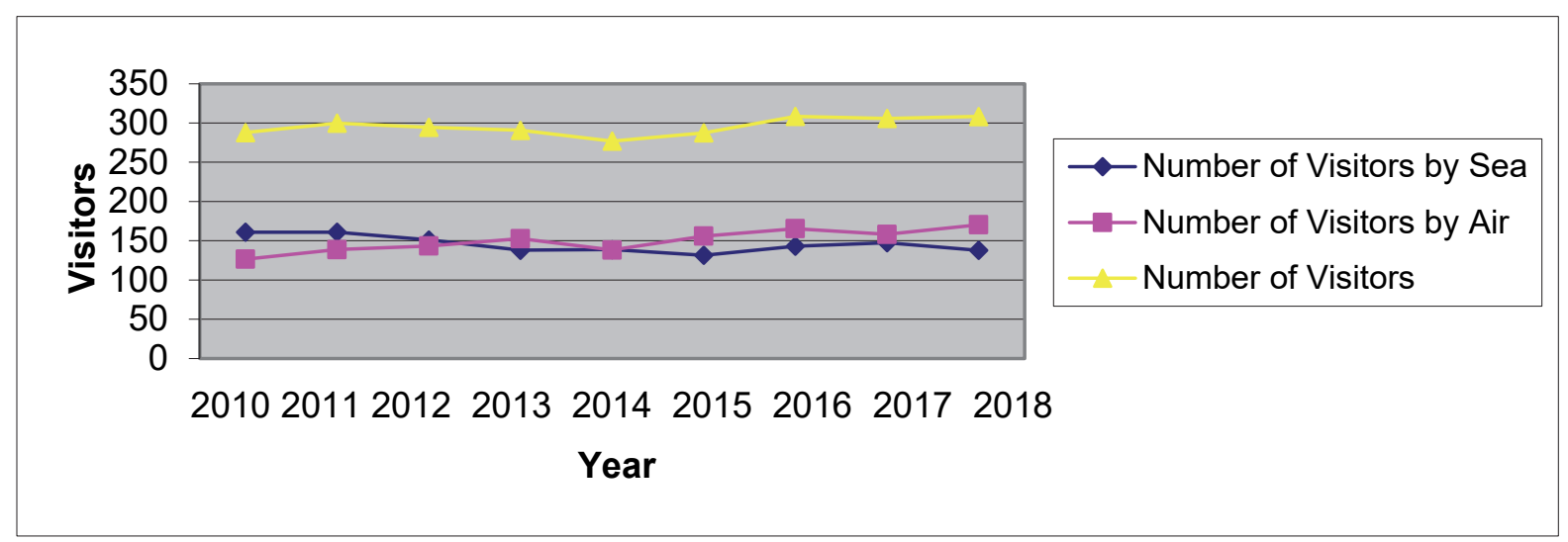

Figure 4. Number of Visitors by Mode of Travel ('000) (Source: Isle of Man Government, 2019)

The data in Figures 4 and 5 and Table 2 taken from The Isle of Man Passenger Survey is collected by the Economic Affairs Department based in the Cabinet Office of the Isle of Man Government through interviews electronically recorded and analysed by the Department (Isle of Man Government, 2019).

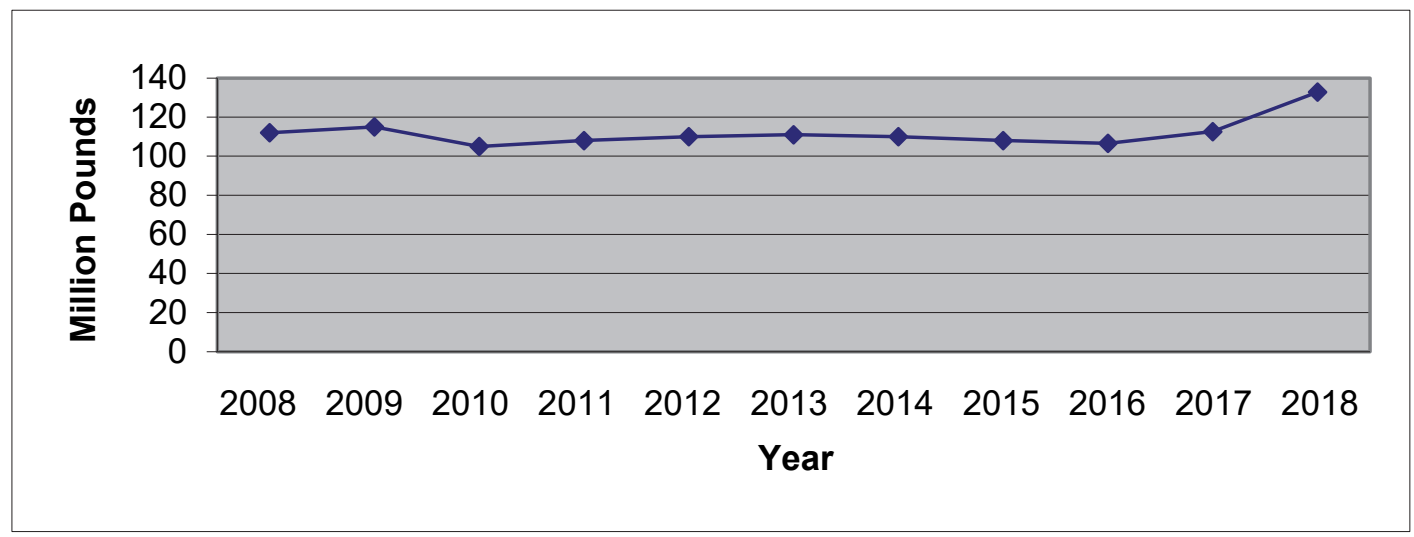

Figure 5. Total Visitor Expenditure at Constant Prices (million pounds) (Source: Isle of Man Government, 2019)

Interviewees in the Passenger Survey are classified according to the following passenger type definitions (Isle of Man Government, 2019):

- Period Visitors in Paid Accommodation (PVPA) - non business visitors who stayed in paid accommodation while visiting the Island.

- Period Visitors Visiting Friends and Relatives (VFR) - non business visitors who stayed with friends or relatives while visiting the Island.

- Business Visitors (BV) - visitors who stayed on the Island for business reasons.

- Day Visitors (DV) - visitors who are non-business and did not stay for the night.

Using these categories Table 2 below gives the number of bed nights stayed by visitors on the Isle of Man for 2018.

Table 2. Isle of Man Number of Bed Nights 2018 (Source: Isle of Man Government, 2019)

\begin{tabular}{llll}
\hline & & Average & Total \\
\cline { 2 - 4 } All Staying Visitors & Air & 4.9 & 754,214 \\
excluding Day Visitors & Sea & 6.3 & 856,301 \\
(DV) & Total & 5.5 & $1,610,515$
\end{tabular}




\begin{tabular}{llll}
\hline Including & & & \\
Period Visitors in Paid & Air & 4.1 & 233,454 \\
Accommodation & Sea & 6.2 & 548,741 \\
(PVPA) & Total & 5.4 & 782,195 \\
Period Visitors Visiting & Air & 6.3 & 372,901 \\
Friends and Relatives & Sea & 6.3 & 246,116 \\
(VFR) & Total & 6.3 & 619,017 \\
Business Visitors (BV) & Air & 3.9 & 147,859 \\
& Sea & 6.9 & 61,444 \\
& Total & 4.5 & 209,303 \\
\hline
\end{tabular}

In terms of visitors on holiday important attractions of the Isle of Man are its history and heritage and the cultural events held on the Island during the year. These are described below and reported in the next section concerning popular cultural events on the Isle of Man.

\section{History and Cultural Heritage}

Historically, as in evidence today, the Isle of Man has a varied and unique heritage. With Castle Rushen, one of Europe's most well maintained castles, it is possible to see how people lived in medieval times and how the Kings and Lords of Man existed. At Peel Castle, to the west of the Isle of Man, the importance of Viking warriors and Christian missionaries can be recounted. The Island has one of the World's biggest operating waterwheels at Laxey which was used for pumping water to the mines nearby. Here it can be seen what life was like for miners, crofters and fishermen. To the south of the Island, not far from the Calf of Man, there is Cregneash which illustrates what it was like to live in an upland crofting community in the nineteenth century. One of the Isle of Man's most important historical structures, Tynwald Hill, gives insight into the history of the Island. This four tiered hill is believed to be constructed using soil from the seventeen parishes of the Island and is a symbol of the Isle of Man as an independent self governing crown dependency.

Most of the Island can be seen by riding on the Manx heritage railways with a network run by horsepower, electricity and steam. An advantage of the network is that many heritage attractions are sited near to railway stations and stops enabling easy access to Manx history. By taking a ride on the Manx Electric Railway from Douglas to Laxey the Isle of Man's mining heritage can be seen, and from here the Snaefell Mountain Railway can be taken or Ramsey can be visited. Alternatively, in Douglas a horse drawn tram can be taken along the Promenade. The south of the Island can also be visited by taking a ride on the Victorian Steam Railway enabling tourists to see the House of Keys which is the previous location of the Manx Parliament.

\section{Cultural Events on the Isle of Man: Findings and Analysis}

In this section we investigate cultural events by providing findings in terms of considering popular events according to their development and nature. Even though these findings may not substantiate cultural events are beneficial for tourism, anecdotal evidence suggests that through their marketing they have a significant role for tourism on the Isle of Man.

Popular cultural events (IOM, 2017) reported below in the findings, and shown in Table 3, are the Manx Competitive Music, Speech and Dance Festival, Manx Litfest, Ramsey-based Shennaghys Jiu, The Mananan International Festival and Yn Chruinnaght - 'the gathering'.

The Manx Competitive Music, Speech and Dance Festival as one of the oldest festivals on the Isle of Man, is better known as the Manx Music Festival or otherwise 'The Guild'. Starting in 1892, choir competitions took place as part of the Isle of Man Fine Art and Industrial Guild. Classes and awards were added during the following years, and included the Manchester Manx Shield, which first took place in 1908 and is still given for the Concert Class for Mixed Choirs. What had commenced as a one day competition has developed into a 9 day festival every April at the Villa Marina. The One hundred and twenty-fifth anniversary of the festival took place for The Guild in 2017 with the competition for the Cleveland Medal.

A recent addition to the Isle of Man's cultural calendar is the Manx Litfest, first held in 2012. Readers, publishers, agents, poets and authors are brought together to celebrate storytelling from around the British Isles. Events take place in late September/early October which inspire the young to read and write. This includes National Story Day 
with poets and authors providing a series of talks, readings and performances to Manx schools. A means for Island writers to make contacts and develop their skills with the publishing industry is provided by Litfest. Also, the delivery of short stories and poetry enable writers to perform before audiences.

The Ramsey based Shennaghys Jiu has been a successful festival and illustrates the belief in the Isle of Man's young people to celebrate and keep traditional culture on the Island. The origin of the festival was from a discussion in a public house resulting in it being founded in 1998. It brings together young artists and performers every Easter holiday from the Celtic nations, including Share na Veg from Bunscoill Rhumsaa, and showcases their talents.

Established in 1975, the Mananan International Festival was championed by the late Sir John Betjeman, who was the festival's first patron. It is held annually during a fortnight in June/July in Port Erin at the Erin Arts Centre. As a prestigious event it attracts world stars in the performing arts to the Island. A wide programme is provided which features lectures, opera (for example The Barber of Seville), films, theatre, jazz and classical music.

Taking place in July Yn Chruinnaght 'the gathering' celebrates Isle of Man culture including its relationship to other Celtic nations. It originated as a festival called Chruinnaght Vanninagh Ashoonagh in 1924, ending at World War II's outbreak. It re-started in 1978 as the five day festival Yn Chruinnaght, to begin with in Ramsey and in Peel from 2007. In 2017 Yn Chruinnaght had a new identity and entered a new era as Celtfest, taking into consideration its increasing modern world diversity and the true nature of the festival's heritage.

Table 3. Isle of Man Popular Cultural Events (Sources: IOM, 2017; Internet)

\begin{tabular}{|c|c|c|c|c|c|c|c|c|}
\hline $\begin{array}{l}\text { Cultural } \\
\text { Event }\end{array}$ & $\begin{array}{l}\text { Cultural } \\
\text { Area }\end{array}$ & $\begin{array}{l}\text { Location } \\
\text { (Place) }\end{array}$ & $\begin{array}{l}\text { Dates } \\
\text { (Start- } \\
\text { Finish) }\end{array}$ & $\begin{array}{l}\text { Duration } \\
\text { (Days) }\end{array}$ & $\begin{array}{l}\text { Frequency } \\
\text { Annually } \\
\text { (PA) }\end{array}$ & $\begin{array}{l}\text { Founded } \\
\text { - First } \\
\text { Held } \\
\text { (Date) }\end{array}$ & $\begin{array}{l}\text { Years } \\
\text { Held } \\
\text { (Number) }\end{array}$ & $\begin{array}{l}\text { Posts on } \\
\text { the } \\
\text { Internet } \\
\text { (Number) }\end{array}$ \\
\hline $\begin{array}{l}\text { Manx } \\
\text { Music, } \\
\text { Festival or } \\
\text { 'The Guild' }\end{array}$ & $\begin{array}{l}\text { Music, } \\
\text { Speech and } \\
\text { Dance }\end{array}$ & $\begin{array}{l}\text { Villa } \\
\text { Marina }\end{array}$ & $\begin{array}{l}\text { During } \\
\text { April }\end{array}$ & $\begin{array}{l}9 \text { day } \\
\text { festival }\end{array}$ & PA & 1892 & 127 & 542,000 \\
\hline $\begin{array}{l}\text { Manx } \\
\text { Litfest }\end{array}$ & Storytelling & Various & $\begin{array}{l}\text { Late } \\
\text { September/ } \\
\text { early } \\
\text { October }\end{array}$ & 7 days & PA & 2012 & 7 & 8,610 \\
\hline $\begin{array}{l}\text { Ramsey } \\
\text { based } \\
\text { Shennaghys } \\
\text { Jiu }\end{array}$ & $\begin{array}{l}\text { Traditional } \\
\text { Manx } \\
\text { Culture }\end{array}$ & Ramsey & $\begin{array}{l}\text { During } \\
\text { Easter }\end{array}$ & 4 days & PA & 1998 & 21 & 884 \\
\hline $\begin{array}{l}\text { Mananan } \\
\text { International } \\
\text { Festival }\end{array}$ & $\begin{array}{l}\text { Performing } \\
\text { Arts }\end{array}$ & $\begin{array}{l}\text { Erin Arts } \\
\text { Centre, } \\
\text { Port Erin }\end{array}$ & June/July & 14 days & PA & 1975 & 44 & 620,000 \\
\hline $\begin{array}{l}\text { Yn } \\
\text { Chruinnaght } \\
\text { 'the } \\
\text { gathering' }\end{array}$ & $\begin{array}{l}\text { Island's } \\
\text { Culture }\end{array}$ & $\begin{array}{l}1978- \\
2006 \\
\text { Ramsey } \\
2007- \\
\text { present } \\
\text { Peel }\end{array}$ & 11-15 July & $\begin{array}{l}5 \text { day } \\
\text { festival }\end{array}$ & PA & $\begin{array}{l}1924- \\
1939 \\
1978- \\
\text { present }\end{array}$ & $\begin{array}{l}14+41 \\
=56\end{array}$ & 11,700 \\
\hline
\end{tabular}

Table 3 presents findings according to eight main factors (cultural area, location (place), dates (start-finish), duration (days), frequency (annually), founded - first held (date), years held (number), and posts on the Internet (number). With regard to cultural area one event focused on music, speech and dance, another on storytelling, two on culture and one on performing arts. In terms of location of the event two were venue based, one had various locations, and two were town based. Concerning the dates of events two were at Easter, two in the Summer, and one in the Autumn. The duration of events varied from four to fourteen days with an average of about eight days. Frequency of event showed that all events were annual. For the date when the events were founded one was first 
held in the nineteenth century, one pre/post war, one in the 1970s, another in the 1990s and one post Millennium. The number of years held varied from seven to one hundred and twenty seven years with an average of 53 years. Finally, regarding the number of posts on the Internet these varied from 884 to 542,000 with an average of about 237,000 posts.

From the findings in this study it can be inferred that popular cultural events (internal factor) (Table 3) can draw on a wider population from outside the Island and a larger number of staying visitors (external factor) (Table 2). Therefore the findings suggest cultural events could have a significant effect on the number of visitors. Although the data shows a suggested fall in some tourist numbers (number of visitors by sea) (Figure 4) in contradistinction to number of visitors by air total visitor expenditure in recent years, although falling from 2009 to 2010 , more or less stabilised from 2011 to 2016, and has increased since (Figure 5).

\section{Conclusion}

For this study a Strengths, Weaknesses, Opportunities and Threats (SWOT) analysis has been carried out to illustrate the internal strengths/weaknesses and external opportunities/threats for the Tourism industry. By doing this, a summary of the analysis of the industry is provided and this enlightens the formulation of future objectives that are sustainable. Attractive external opportunities can be matched with strengths highlighting weaknesses to be dealt with and threats to be overcome. A SWOT analysis for the Tourism industry is provided in Table 4.

Table 4. Strengths, Weaknesses, Opportunities and Threats for the Isle of Man tourism industry

\begin{tabular}{|c|c|c|}
\hline \multirow[t]{6}{*}{ INTERNAL } & STRENGTHS & WEAKNESSES \\
\hline & Conservation and preservation & Visitor management \\
\hline & Education-host community and tourists & conservation \\
\hline & Employment opportunities & Limited tourist services-walking tours \\
\hline & $\begin{array}{l}\text { Historic sites could be listed if already not to help } \\
\text { protect them }\end{array}$ & $\begin{array}{l}\text { Lack of opportunities to view historic } \\
\text { sights and tours }\end{array}$ \\
\hline & & Authenticity issues \\
\hline \multirow[t]{6}{*}{ EXTERNAL } & OPPORTUNITIES & THREATS \\
\hline & Employment opportunities & Increasing cost of travel \\
\hline & Educating with regard to heritage & Politics \\
\hline & \multirow{3}{*}{$\begin{array}{l}\text { Isle of Man is not just about sport tourism - wider } \\
\text { tourism market i.e. eco tourism, heritage }\end{array}$} & Marketing economic factors \\
\hline & & Holiday competition \\
\hline & & Economic climate - funding issues \\
\hline
\end{tabular}

Table 4 shows that the internal strengths are conservation and preservation, education (host community and tourists), employment opportunities and listing of historic sites. The internal weaknesses include visitor management, conservation, limited tourism services, lack of opportunities to view historic sites and authenticity issues. External opportunities are employment, educating with regard to heritage and the Isle of Man not just being about sport tourism (e.g. motor cycle races) but a wider tourism market involving ecotourism and heritage. Finally, external threats are the increasing cost of travel, politics, marketing economic factors, holiday competition and economic climate including funding issues.

Table 5. Tourism Strategy Proposal

\begin{tabular}{lll}
\hline Eco tourism & $\begin{array}{l}\text { Invest in ecotourism by working alongside farmers } \\
\text { unions in order to create links and avoid conflict }\end{array}$ & $\begin{array}{l}\text { Expanding more on pilgrimage tourism } \\
\text { between both the tourism and farming sector. }\end{array}$ \\
$\begin{array}{ll}\text { Forming clear aims and objectives for such projects } \\
\text { sites on Isle of Man. }\end{array}$ & $\begin{array}{l}\text { This will be achieved by working in } \\
\text { also need to be drawn up so that both parties know } \\
\text { what is involved. }\end{array}$ & $\begin{array}{l}\text { partnership with one another. Islands } \\
\text { are steeped in religious history. }\end{array}$ \\
\hline
\end{tabular}


more food and drink festivals.

Educational opportunities need to be put in place in order to involve the local community of the changes taking place.

\begin{tabular}{ll}
\hline Heritage & $\begin{array}{l}\text { Each part of the island has a tremendous amount of } \\
\text { tourism }\end{array}$ \\
& $\begin{array}{l}\text { history and there are historic landmarks which } \\
\text { represent this. These need to be expanded on as with } \\
\text { heritage tourism }\end{array}$
\end{tabular}

\section{Transport tourism}

Transport tourism on the Island could be developed further.

Table 5 conveys that there is a need to invest in ecotourism, expanding pilgrimage tourist sites, developing gastronomy tourism by introducing more food and drink festivals, and enhancing heritage tourism and transport tourism.

By responding to the research question, this study investigated the processes involved in the modern decline of tourism on the Isle of Man (Canavan, 2015) in relation to cultural events. A successful events programme promoted by the Isle of Man Government with an emphasis on cultural events has seen a positive response to the Isle of Man Tourism Visitor Economy Strategy (Isle of Man Government, 2013). It is evident in the findings of this study that the internal factor of cultural events (Table 3 ) could attract a larger population outside the Island and draw a larger number of staying visitors as an external factor (Table 2). The findings of this study suggest cultural events could provide a stimulus to tourist numbers to the Isle of Man, which is crucial to the evolution of a strategy for culture.

The article originally aimed to consider the issues of cultural events and tourism on the Isle of Man. This was according to the fact that research on events is an increasing specialty especially in relation to the development of communities (Powell et al., 2010, 2011). The study also shows cultural events could have a direct effect in an island setting (Thomas and Thomas, 2012; Thomas et al., 2017) and will be of interest to academics and a wider readership and also land researchers. In addition to reporting data showing a decline in certain tourist numbers (Figure 4) total visitor expenditure at constant prices (million pounds) in recent years has been considered (Figure 5) to provide a basis for a comprehensive understanding of the evolution of Isle of Man tourism (Table 2). Community cultural events were reported and popular cultural events (IOM, 2017) on the Isle of Man were investigated (Table 3) and this included consideration of data in terms of cultural event, cultural area, location (place), dates (start-finish), duration (days), frequency (annually), founded - first held (date), years held (number), and posts on the Internet (number). Even though these findings do not overtly provide evidence cultural events will impulse tourism it is deduced that they will have a significant effect on Isle of Man tourism.

In conclusion it seems that cultural events tourism could be a great added advantage to the economy of islands such as the Isle of Man because it is another source of income that already has the beauty of the landscape to start with. All other added aspects to tourism within events management is an extra gap in the market explored as another business industry within tourism that all islands should consider due to their geographical isolation which gives more emphasis to these areas to invest in tourism as one of the main economic backdrops as a form of employment. Any island faces many challenges and other alternative industries such as tourism are a really good way to bring some financial stability to such a place. We need to all make the most of the natural beauty and heritage within our communities and be proud of our identity just like other countries around the world. Finally, the research reported in this paper will be useful for future management development plans of the tourism industry in the research area, since it contributes to current knowledge through highlighting the importance of cultural events for the development of tourism on the Isle of Man.

\section{References}

Bowdin, G, et al. (2006). Events Management. Amsterdam: Elsevier. https://doi.org/10.4324/9780080457154

British Arts Festival Association (2008). Audiences at Cultural Events. London: BA.

British Broadcasting Corporation (BBC) (2016). Map of the Isle of Man. BBC News, 21 April 2016.

Caanavan, B. (2015). Marketing a tourism industry in late stage decline: The case of the Isle of Man. Cogent Business and Management, 2(1), 1-15. https://doi.org/10.1080/23311975.2015.1004227

Engels, D. W. (1980). Looking forward via hindsight: A rationale for reviewing our ideological roots. The Personnel and Guidance Journal, 59, 183-185. https://doi.org/10.1002/j.2164-4918.1980.tb00527.x 
IOM (2017). Isle of Man Stamps \& Coins. Issue Number 156.

Isle of Man Government (2013). Tourism Visitor Strategy. Douglas: Economic Affairs Cabinet Office.

Isle of Man Government (2019). Isle of Man Passenger Survey Report 2018. Douglas: Economic Affairs Cabinet Office, April, GD 2019/0026.

Johnson, H. C. (2016). Encountering Urbanization on Jersey: Development, Sustainability, and Spaciality in a Small Island Setting. Urban Island Studies, 2, 50-71. https://doi.org/10.20958/uis.2016.3

Langen, F., \& Garcia, B. (2009). Measuring the Impacts of Large Scale Cultural Events: A Literature Review. Liverpool, Impacts 08, Joint programme of the University of Liverpool and Liverpool John Moores University Commissioned by Liverpool City Council.

Leedy, P. (2001). Practical Research. New Jersey: Merrill.

Malecki, E. J. (1991). Technology and Economic Development: The Dynamics of Local, Regional, and National Change. New York: Longman.

Montgomery, J. (1999). Historical Research Methods. Faculty of Education, University of Aberdeen, Aberdeen, Scotland, pp. 1-3.

Mousavi, S. S., Doratli, N., Mousavi, S. N., \& Moradiahari, F. (2016). Defining Cultural Tourism, International Conference on Civil, Architecture and Sustainable Development (CASD-2016). Dec. 1-2, 2016, London(UK), pp. 70-75.

OECD. (2009). The Impact of Culture on Tourism. Paris: Organisation for Economic Co-operation and Development.

Powell, L., Thomas, S., \& Thomas, B. (2010). Regeneration schemes in the South Wales Valleys: A stimulus for innovative heritage enterprise development. International Business Management Journal, 4(3), 177-188. https://doi.org/10.3923/ibm.2010.177.188

Powell, L., Thomas, S., \& Thomas, B. (2011). Innovation and heritage entrepreneurship development in the South Wales Valleys. Annals of Innovation and Entrepreneurship, 2(1), 1-8. https://doi.org/10.3402/aie.v2i1.6001

Schumaker, S., \& McMillan, J. H. (1993). Research in education: A conceptual introduction (3rd ed). New York: Harper Collins College Publishers.

Seldes, G. (1985). The great thoughts: From Abelard to Zola, from ancient Greece to contemporary America, the ideas that have shaped the World. New York: Ballantine Books.

Sheeley, V. L. (2002). Historical Research Methods, Research Document, Department of Educational Leadership. Bowling Green, KY: Western Kentucky University, pp. 1-3.

Thomas, B., \& Thomas, S. (2012). Cultural Events and Tourism in Jersey. The International Journal of Research into Island Cultures, 6(1), 114-131.

Thomas, B., Thomas, S., \& Powell, L. (2017). The Development of Key Characteristics of Welsh Island Cultural Identity and Sustainable Tourism in Wales. Scientific Culture, 3(1), 23-39.

Umphrey, M. L. (2002). Creating an Original Interpretation: The Research Process. Retrieved from http://www.edheritage.org/wolves/researchmethods.htm, pp. 1-2.

United Nations. (2020). World Population Prospects: The 2020 Revision. Department of Economic and Social Affairs, Population Division, United Nations, 2020.

Visit Isle of Man. (2019). Retrieved from https://www.visitisleofman.com/getting-here.

Worldometers (2020). Retrieved from www.Worldometers.info

Yeoman, I. et al. (2004). Festival and Events Management: An International Arts and Culture Perspective. Amsterdam: Elsevier.

Young, R. (1987). The Role of Historical Research in Higher Education. ASHE Annual Meeting Paper.

\section{Copyrights}

Copyright for this article is retained by the author(s), with first publication rights granted to the journal.

This is an open-access article distributed under the terms and conditions of the Creative Commons Attribution license (http://creativecommons.org/licenses/by/4.0/). 